\section{Discrepancies among ecological, household, and individual data on fruits and vegetables consumption in Brazil}

\author{
Discrepância entre dados ecológicos, domiciliares \\ e individuais sobre o consumo de frutas \\ e hortaliças no Brasil
}

\begin{abstract}
${ }^{1}$ Faculdade de Saúde Pública, Universidade de São Paulo, São Paulo, Brasil. 2 London School of Hygiene and Tropical Medicine, University of London, London, UK.

Correspondence R. M. Claro

Departamento de Nutrição, Faculdade de Saúde Pública, Universidade de São Paulo. Av. Dr. Arnaldo 715, São Paulo, SP 01246-904, Brasil. rclaro@usp.br
\end{abstract}

\begin{abstract}
Information on fruits and vegetables consumption in Brazil in the three levels of dietary data was analyzed and compared. Data about national supply came from Food Balance Sheets compiled by the FAO; household availability information was obtained from the Brazilian National Household Budget Survey (HBS); and actual intake information came from a large individual dietary intake survey that was representative of the adult population of São Paulo city. All sources of information were collected between 2002 and 2003. A subset of the HBS, representative of São Paulo city, was used in our analysis in order to improve the quality of the comparison with actual intake data. The ratio of national supply to household availability of fruits and vegetables was 2.6 while the ratio of national supply to actual intake was 4.0. The discrepancy ratio in the comparison between household availability and actual intake was smaller, 1.6. While the use of supply and availability data has advantages, as lower cost, must be taken into account that these sources tend to overestimate actual intake of fruits and vegetables.
\end{abstract}

Fruit; Vegetables; Food Consumption, Diet Surveys

\author{
Rafael Moreira Claro 1 \\ Patricia Constante Jaime 1 \\ Karen Lock 2 \\ Regina Mara Fisberg 1 \\ Carlos Augusto Monteiro ${ }^{1}$
}

\section{Introduction}

Consumption of five or more servings of fruits and vegetables per day is recommended worldwide to reduce the risk of cardiovascular diseases and other chronic diseases (including diabetes and some cancers), through the intake of combinations of micronutrients, antioxidants, fibers and other bioactive substances present in these foods 1,2,3,4,5,6. A growing body of evidence also indicates that a diet rich in fruits and vegetables could be associated with a reduced risk of obesity through smaller weight gains throughout the life cycle $6,7,8$.

However our ability to research the health effects of fruits and vegetables, with regard for nutrition policy to promote its adequate consumption, is limited by the challenges which exist in how to measure accurately, and therefore how to monitor, population consumption of fruits and vegetables. In Brazil, nationally representative or large population surveys of individual dietary intake (IDIS) are rare and the few existing studies are either too old or performed with different methodologies 9,10. This kind of survey provides the most appropriate information in this context since they generally may be stratified by age, gender and income level, enabling the identification of high-risk population groups 11,12. However, supply or availability data are also important since it provide useful information of food and nutrient availability for human consumption. In 
Brazil this type of data is available at national and household level, respectively from Food Balance Sheets - FBS compiled by the Food and Agriculture Organization (FAO) of the United Nations (FAOSATAT; http://faostat.fao.org/site/368/de fault.aspx\#ancor) and from Brazilian Household Budget Surveys (HBS) conducted by the Brazilian Institute of Geography and Statistics (IBGE) 13. FBS/FAO data refers to the production of food in the country adjusted according to importation, exportation, national stock level, wastage and non dietary uses such as for livestock and seeds. HBS data refers to food acquisitions made for family consumption, with no further adjustment. These data also have advantages in that they are generally less costly (as the data are regularly collected for use across several research areas), and, very often, provide the most comprehensive trend data available.

Despite the availability in Brazil of these three types of data, very little research has been conducted to examine the differences in fruits and vegetables estimations between data sources. This paper analyses the discrepancies between the national supply, household acquisitions (proxy information of the household availability) and information on population intake of fruits and vegetables in Brazil. We focused on national FBS/FAO data, a nationally representative HBS and a large food intake survey from São Paulo city, all collected during the same period (between 2002 and 2003).

\section{Methods}

\section{Sources of data on availability and consumption of fruits and vegetables}

The results in this paper are based on a new analysis of existing data collected by several external sources. Table 1 provides a summary of the 3 data sources used.

\section{- National supply of fruits and vegetables FBS/FAO}

Brazilian data on per capita supply of fruits and vegetables (FBS/FAO codes 2,919 and 2,918 respectively) was downloaded from the FAOSTAT database on the FAO internet website (http:// faostat.fao.org/site/368/default.aspx\#ancor). Potatoes, pulses and starchy vegetables were not included in order to be consistent with current international dietary recommendations 14 . The FBS methodology has been analyzed in detail elsewhere 15. FAO data from 2002 and 2003 were used to estimate an average value of fruits and vegetables supply. This period was primarily chosen in order to cover the data collection periods of all other surveys used in this study (HBS and food intake information), and was also necessary to reduce the influence of annual variations in the data.

As the information originally reported on FBS/FAO refers only to the gross weight available of each item, correction factors (estimated by the IBGE based on food consumption patterns of the Brazilian population) were employed to determine the amount of fruits and vegetables available for human consumption based exclusively on its edible fraction 16 . The per capita supply of fruits and vegetables at national level (available on the FBS/FAO), in each year, is defined as the division between the total available amount of fruits and vegetables and the number of residents in the country. Finally, the fruits and vegetables supply for Brazil was defined as the mean value between the per capita supply of 2002 and 2003.

\section{- Household availability of fruits and vegetables: data collected for the HBS}

Data from the HBS conducted by IBGE between June 2002 and July 2003 were used to estimate household availability of fruits and vegetables 13 . The 2002-2003 Brazilian HBS is a national representative survey conducted with 48,470 households from urban and rural areas in all 26 states and the Federal District. Further information about the survey has been published elsewhere 13 . In order to improve the comparison with the intake data available only households belonging to the city of São Paulo (HBS-SP) were used in our estimations (approximately 500 households; the complex sampling design adopted in the survey allows this stratification) 13 . The survey recorded detailed information (including the exactly amount acquired of each item) on all food and beverage expenses made for family consumption during a period of seven consecutive days. Additionally, information about non-monetary acquisitions (such as donations and self-production) was also recorded.

As the information originally reported on the Brazilian HBS refers only to the gross weight available of each acquisition (like FBS/FAO), correction factors were employed to determine the availability of fruits and vegetables at household level (edible parts only) 16 . The per capita availability of fruits and vegetables at household level was defined as the division between the total acquired amount (edible parts only) of fruits and vegetables and the total number of individuals in the sample in the city of São Paulo. Original 
Table 1

Summary of the data sources used for the comparisons.

\begin{tabular}{|c|c|c|c|c|}
\hline Data source & Year & Sampling method & n (population) & Data collection method \\
\hline \multicolumn{5}{|c|}{ National supply } \\
\hline FBS/FAO & 2002-2003 & * & * & $\begin{array}{l}\text { Federal government information } \\
\text { on food production adjusted } \\
\text { according to importation, } \\
\text { exportation, foods lost in storage, } \\
\text { transportation and processing, fed } \\
\text { to livestock and used for seeds } \\
\text { and or for non-dietary purposes. }\end{array}$ \\
\hline \multicolumn{5}{|c|}{ Household availability } \\
\hline HBS & $2002-2003$ & $\begin{array}{l}\text { Multistage cluster sampling, } \\
\text { stratified by geographic location } \\
\text { and economic level (nationally } \\
\text { representative sample). }\end{array}$ & $\begin{array}{c}\text { 48,470 households in Brazil } \\
\text { (household members); } 470 \text { in São } \\
\text { Paulo city }\end{array}$ & $\begin{array}{l}\text { Household survey. Detailed } \\
\text { information on all food and } \\
\text { beverage acquisitions made for } \\
\text { family consumption during a } \\
\text { period of seven consecutive days. }\end{array}$ \\
\hline \multicolumn{5}{|c|}{ Individual intake } \\
\hline IDIS & 2003 & $\begin{array}{l}\text { Multistage cluster sampling } \\
\text { stratified by geographic location } \\
\text { and economic level (São Paulo } \\
\text { City representative sample). }\end{array}$ & $\begin{array}{l}1,477 \text { individuals (adults older than } \\
20 \text { years of age) }\end{array}$ & $\begin{array}{l}\text { Individual dietary intake survey. } \\
\text { Single 24-hour food recall }\end{array}$ \\
\hline
\end{tabular}

FBS/FAO: Food Balance Sheets compiled by the Food and Agriculture Organization; HBS: Brazilian Household Budget Surveys conducted by the Brazilian Institute of Geography and Statistics (IBGE); IDIS: Individual Dietary Intake Survey.

* Does not apply.

sample weights were employed allowing for extrapolation of our results to the whole population of São Paulo city.

\section{- Estimate of fruits and vegetables intake: data collected for the study Food Surveys in the City of São Paulo, an IDIS}

The estimate of dietary intake used belongs to a population-based household survey carried out in the city of São Paulo between March and December 2003 called Food Surveys in the City of São Paulo (ISA), a project coordinated by the School of Public Health at the University of São Paulo (FSP/USP). This study is part of a wider project on public policies, entitled Health Survey of the State of São Paulo - Population-based Household Health Survey, funded by the Health Department of the city of São Paulo. A total of 1,477 individuals were included in the study sample, in the following defined age and gender groups: 20 to 59 years/males; 20 to 59 years/females; 60 years and more/males; and 60 years and more/females. Further information about the survey has been published elsewhere 17 . This study was selected for our comparisons because the data collection period is similar to the last Brazilian HBS, and because the survey has good representativeness of the population. Furthermore, several age groups were surveyed, non-response was satisfactory and properly documented 17 , the methods used to collect data were also adequate and satisfactory (24-hour food recall) and data were available on fruit and vegetable intake in grams per day. The per capita intake of fruits and vegetables was defined as the division between the total intake of fruits and vegetables reported by all subjects and the total number of individuals. Original sample weights were employed allowing for extrapolation of our results to the whole adult population of São Paulo city.

\section{Data analysis}

Comparisons between national supply, household availability and estimated intake of fruits and vegetables were made by calculating the ratios of FBS/FAO:HBS-SP, FBS/FAO:IDIS and HBS-SP:IDIS. Ratio values greater than 1 indicate that availability or supply data tend to overestimate population intakes while values smaller than 1 indicate that availability or supply data tend to underestimate population intakes. 


\section{Results}

Table 2 presents the estimates of fruits and vegetables supply (FBS/FAO data), availability (HBSSP data) and intake (IDIS data). The estimated national per capita supply of fruits and vegetables was around $300 \mathrm{~g}$ per day, less than the World Health Organization (WHO) 18 recommended minimum daily intake (of $400 \mathrm{~g}$ per day).

The comparison of FBS/FAO, HBS-SP and IDIS data is also presented in Table 2 . All the scenarios showed a ratio of supply or availability to intake greater than one, showing unsurprisingly that availability data tends to overestimate individual intakes in Brazil. The ratio of fruits and vegetables national supply to the estimated household availability (HBS-SP data) of fruits and vegetables was 2.55 (greater for fruits than for vegetables). The ratio of national supply to the actual intake was even greater, 4.01. However, the discrepancy is much smaller in the comparison between HBS-SP and IDIS (a ratio of 1.57 for fruits and vegetables grouped together).

\section{Discussion}

Based on this comparison of FBS/FAO, HBS and food intake data it appears that methods based on supply or availability of fruits and vegetables (respectively FBS/FAO and HBS data) tend to overestimate individual intake of these foods. However the level of discrepancy between supply, availability and intake varied depending on the data source. There was a greater difference between intake data and national supply data than for household availability, and greater discrepancies for estimates of fruits compared with vegetables consumption.
Some level of overestimation was expected, as FBS/FAO and HBS data are designed to reflect, respectively, food supply and availability patterns, in national and household levels, rather than actual dietary intake 19,20. The greater overestimation found in FBS/FAO data, in relation to that found in HBS data, was also expected. While both data sources include wastage at household level, FBS/FAO data may also include wastage at the processing and retail level increasing the discrepancy with actual intake 21 .

A previous study comparing FBS/FAO and IDIS data in 15 countries (in the Americas, Europe, Asia and the Western Pacific), also found a tendency of national supply data to overestimate intake in fourteen of these countries 22 . The level of discrepancy between the two sources of information varied considerably among countries, both within and between regions. While the general tendency found in our study is the same, the magnitude of overestimation established for Brazil was greater than the ones estimated previously for all other countries. The highest ratios of discrepancy were found in some developed countries, namely Israel (2.70) and the United States (2.38). Most of the other countries presented ratios of between 1 and 2, including some emerging economies of the developing world like China (1.83), Russia (1.52) and other former Soviet Union countries (like Latvia, 1.38, and Lithuania, 1.21), and countries from western Europe (like Belgium, 1.36, Denmark, 1.62, and Italy, 1.89). The only exception was Finland, where the FBS/FAO data appeared to slightly underestimate individual intakes (0.93). The median FAO/FBS:IDIS ratio for all the 15 countries was 1.51 (even though this value involves large variations between-country) 22 . One important difference to highlight in this previous study is

\begin{tabular}{|c|c|c|c|c|c|c|}
\hline & \multicolumn{3}{|c|}{ g/per capita/day } & \multirow{3}{*}{$\begin{array}{c}\text { FBS/FAO: } \\
\text { HBS-SP }\end{array}$} & \multirow{3}{*}{$\begin{array}{c}\text { FBS/FAO: } \\
\text { IDIS }\end{array}$} & \multirow{3}{*}{$\begin{array}{c}\text { HBS-SP: } \\
\text { IDIS }\end{array}$} \\
\hline & FBS/FAO & HBS-SP * & IDIS/ISA * & & & \\
\hline & 2002-2003 & 2002-2003 & 2003 & & & \\
\hline Fruits & 193.92 & 62.40 & 46.03 & 3.11 & 4.21 & 1.36 \\
\hline Vegetables & 101.87 & 53.70 & 27.77 & 1.90 & 3.67 & 1.93 \\
\hline Fruits and vegetables & 295.79 & 116.10 & 73.80 & 2.55 & 4.01 & 1.57 \\
\hline
\end{tabular}

ISA: Food Surveys in the City of São Paulo.

* Data for São Paulo city only. 
that the data came from a range of different study designs, conducted during different periods over approximately 20 years (from 1980 to 1999). Thus making comparisons - between the countries in this previous study or to our estimations for Brazil - susceptible to bias due to both methodological issues, and to social and political changes that might have taken place during this period.

Another former study compared FBS/FAO and HBS data in 18 European countries and, likewise, found a tendency of FBS/FAO data to overestimate HBS data in all of these countries, with discrepancy ratios ranging from 1.05 (in Finland) to 2.07 (in Portugal) with median FBS/FAO:HBS ratio for all the 18 countries of 1.42 (once again involving large variations between countries) 23 . The original data for this former study, likewise, came from studies conducted during different periods over a time span of 20 year (1980 to 2000) once again making comparisons - between the countries or to our estimations - susceptible to the same bias mentioned previously.

The estimations presented in the present paper are subject to several limitations, relating mostly to the limitations of each data source employed. Table 3 provides a summary of the impact of the main sources of errors on the ratios of discrepancy estimated, described in detail in the next paragraphs.

The accuracy of FBS/FAO data depends on the reliability of the underlying basic statistics of population, supply and utilization of foods which, in the case of Brazil, are provided by the national health, nutrition and agricultural authorities 11,20,24. In fact, data in the statistics for non-food purposes (such as manufacture, as well as in those of commercial and government stocks and food processing industry) were missing in many food items in the FBS used in this study 12 , possibly reducing the global accuracy of the data. Furthermore, the methodology applied to determine wastage during production can make FBS estimates vulnerable to error (often estimates about waste are based on a small number of surveys or even on country expert opinions) 20 . In order to reduce the effect of potential annual variations in coverage and accuracy of the data used in our comparisons, two years of FAO data were used. We also explored a longer time period in order to verify the consistency of our information, and concluded that the estimated value was coherent with the values estimated for the period of 1999-2001 (data not shown). Additionally, FAO claims to verify the external consistency of the FBS/FAO data using supplementary information such as household survey results, as well as the application of relevant technical, nutritional and economic knowledge, in an attempt to reduce the impact of these data limitations 20 .

While HBS are less vulnerable to some of the bias that may be present on FBS/FAO they also have important limitations. In the case of the Brazilian HBS 2002-2003 the information about food acquisition away from home was not detailed enough and could not be included in the present study. This should not be a major limitation as the largest part of food consumption in Brazil is still done in the household. During the period of the survey, the expenses for food away from home (a proxy indicator for the share of food consumed away from home) were approximately one fifth of the total food expenses 25 . Hypothetically, if food away from home was also included, the amount of fruits and vegetables available at household level could increase by approximately $15 \%$, from the estimated 117 to $135 \mathrm{~g} /$ per capita/day. While this could represent an important change into our estimations it is certainly not enough to explain the discrepancies found in our study (in fact it would increase the HBS-SP:IDIS ratio). Likewise, information about the food stock in the households was not available. This should not represent an important limitation to our study as the HBS data collection lasted for an entire year, and no changes in the stocks were expected in this period. The use of a subset of the Brazilian HBS (data for São Paulo city only) in our analysis was necessary to improve the accuracy of the comparison with IDIS data; however it can be seen as a limitation in the comparison with FSB/FAO data. Based on the whole set of information of the Brazilian HBS, the discrepancy ratio between FBS/FAO and HBS data would be 3.06 , with magnitude slightly greater but agreeing in direction with the ratio estimated using the HBS-SP data set.

As the information available on FBS/FAO and HBS are on an "as purchased" basis (including both edible and non-edible parts) the use of correction factors, as employed in our study, was necessary in order to remove the non-edible fraction of each item reducing the expected difference between the availability and actual intake of fruits and vegetables. The correction factors employed in this study came from a national representative study conducted by IBGE 16 . The factors represent the average ratio between net (edible fraction only) and gross weight (as purchased) of each food item, both estimated directly, by weighting food items in the households participating in the study 16 . The mean value for the correction factors used was 0.71 for fruits and 0.90 for vegetables (i.e., on average $10 \%$ of the purchased amount of vegetables correspond to non-edible parts). While it is natural to believe 
Potential factors affecting the discrepancy ratio between national availability (Food Balance Sheets compiled by the Food and Agriculture Organization - FAO/ FBS), household availability (Brazilian Household Budget Surveys - HBS) and actual intake of fruits and vegetables.

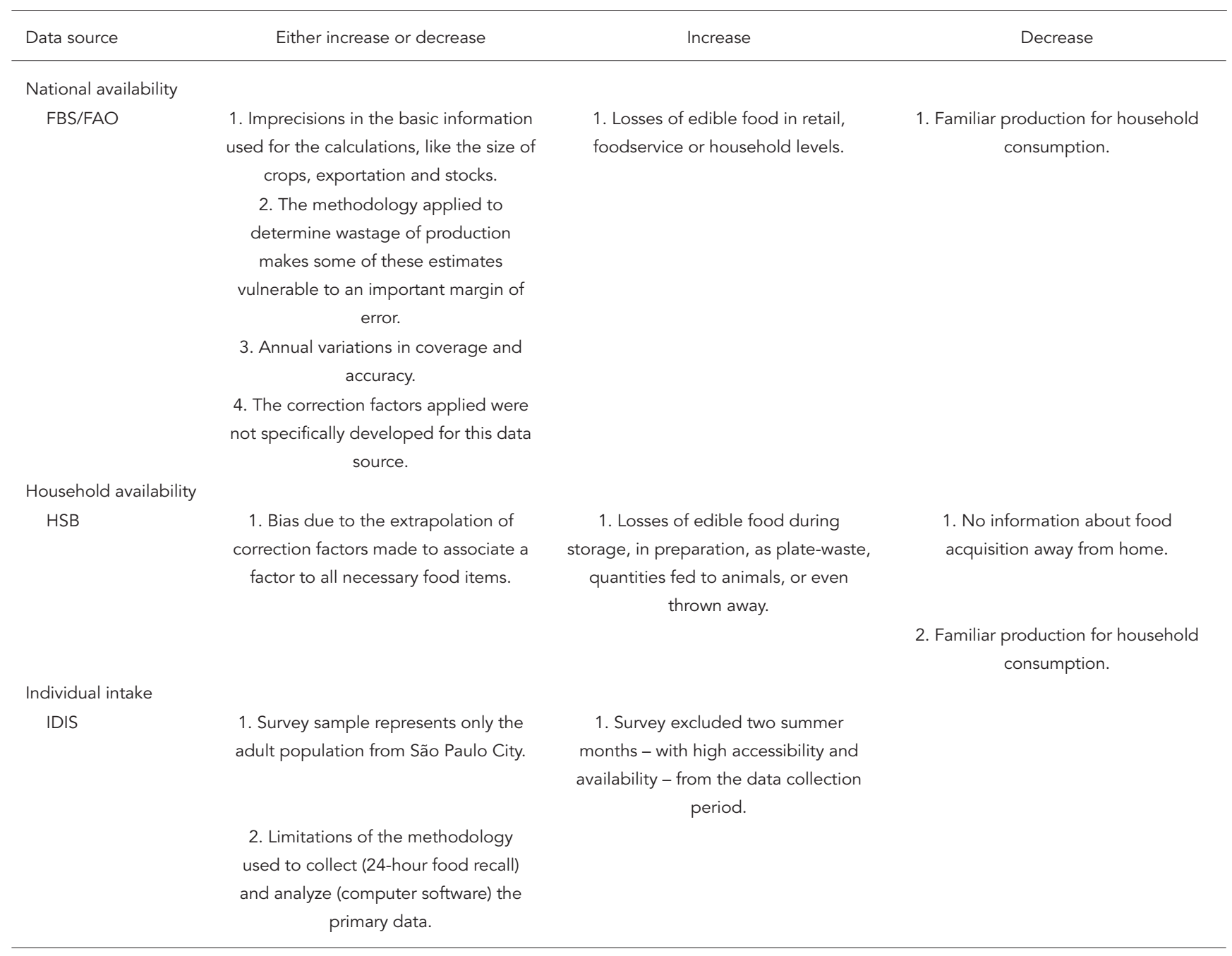

that the correction factor for FBS/FAO and HBS could be different, the data applied in our study is by far the most complete and accurate set of information available for this use in Brazil. Without employing the correction factors, the estimated national supply and household availability of fruits and vegetables were, respectively, 395 and $148 \mathrm{~g} /$ per capita/day, thus increasing the discrepancy between availability and actual intake estimated in our study.

The main limitation of the intake data used is probably related to its study population. While the use of nationally representative data is strongly desirable for the kind of comparison conducted in our study, such information is not available for Brazil. The use of the São Paulo city representative IDIS data can be argued to be a satisfactory alternative as it is representative of the adult population of the biggest city in the country, with approximately 11 million residents (IBGE. 2000 Demographic Census. http://www. ibge.gov.br). In this sense, data from adult populations living in all 26 state capitals (and the Federal District) from Brazil indicate small ranges in the variation of the pattern of consumption of fruits and vegetables in this population 26 . In addition, it is important to note that this survey was conducted during the period March to December, thus excluding two summer months, a time of year more favorable to the intake of fruits and vegetables as accessibility and availability are at core levels, probably reducing the 
average level of consumption estimated by the survey (increasing the discrepancy with availability and supply data). Finally, IDIS data have a limited precision as they are highly influenced by the capacity of the respondents to provide accurate information on their intake, and by the fact that most of the procedures involved in measuring dietary intake can lead to changes in behavior 11,28,29. Strong evidence indicates that self-reported energy intakes underestimate energy needs. This evidence comes from studies in which energy needs were derived from weight maintenance data 29,30 , doubly labeled water assessments 31 , and total energy expenditure prediction equations 32,33 . However, none of these studies have examined the measurement error according to food groups. While it is not possible to predict the magnitude of this error in the information used in our study, some level of underestimation is probably present (increasing the difference between household acquisition and intake information).

Our results show that availability for consumption is by no means identical with intake pattern. Ideally all countries would conduct repeated, nationally representative dietary intake surveys allowing precise investigation of food consumption patterns. However the estimates from FBS/FAO, HBS and IDIS should be seen as complementary. The three levels of data provide useful information (about national supply, availability and reported intake of food in the population) and countries should optimize the benefits of conducting all types of data collection depending on resources available 19,22. Regarding nutrition policy, FBS/FAO and HBS are important as they indicate the sufficiency of supply in national and household levels respectively. IDIS are also important as the amount of food actually consumed may be much lower than the available amount (or even the purchased amount), depending on the degree of losses of edible food during storage, in preparation and cooking, as plate-waste, or quantities fed to domestic animals and pets, or even thrown away.

The results of this study indicate some level of fruit and vegetable wastage in Brazil. These results are especially important as they contradict the idea that in developing countries the quantities of food available for consumption are closer to the real levels of consumption than in developed countries, assuming lower levels of waste 14,19. Future policy should investigate actions that could reduce the level of wastage of fruits and vegetables in Brazil which is likely to have both environmental and health benefits.

\section{Resumo}

Dados sobre o consumo de frutas e hortaliças no Brasil, em três níveis de informação, foram analisados e comparados. Dados sobre a oferta nacional foram obtidos em Folhas de Balanço de Alimentos da FAO; a disponibilidade domiciliar de frutas e hortaliças baseou-se em resultados da Pesquisa de Orçamentos Familiares (POF); informações sobre o consumo de frutas e hortaliças foram obtidas em um inquérito de consumo alimentar representativo da população adulta do $\mathrm{Mu}$ nicípio de São Paulo. Todas as informações referem-se ao período entre 2002 e 2003. Uma subamostra dos domicílios da POF, representativa da cidade de São Paulo, foi utilizada a fim de melhorar a qualidade da comparação com dados de consumo de folhas e hortaliças. A razão entre a oferta nacional e a disponibilidade domiciliar de frutas e hortaliças foi de 2,6, enquanto a razão entre oferta nacional e o seu consumo foi de 4,0. A razão entre a disponibilidade domiciliar e o consumo foi de 1,6. Embora o uso de dados da oferta e disponibilidade de frutas e hortaliças apresente certas vantagens, como o menor custo, sua utilização deve levar em conta a tendência a superestimar o consumo de frutas e hortaliças.

Frutas; Vegetais; Consumo de Alimentos; Inquéritos sobre Dieta 


\section{Contributors}

R. M. Claro and P. C. Jaime collaborated in the study design, data analysis, write up of the article and revision of the final draft. K. Lock, C. A. Monteiro and R. M. Fisberg contributed in the data analysis and revision of the manuscript.

\section{Acknowledgments}

The study received financial support from the São Paulo State Research Foundation (FAPESP) through a doctoral grant awarded to R. M. Claro (process $n^{\circ}$. 2007/00064-8).

\section{References}

1. World Health Organization. Report of a Joint WHO/FAO Expert Consultation. Diet, nutrition and the prevention of chronic diseases. Geneva: World Health Organization; 2003. (WHO Technical Report Series, 916).

2. Krauss RM, Deckelbaum RJ, Ernst N, Fisher E, Howard BV, Knopp RH, et al. Dietary guidelines for healthy American adults: a statement for health professionals from the Nutrition Committee, American Heart Association. Circulation 1996; 94:1795-800.

3. Joshipura KJ, Hu FB, Manson JE, Stampfer MJ, Rimm EB, Speizer FE, et al. The effect of fruits and vegetable intake on risk for coronary heart disease. Ann Intern Med 2001; 134:1106-14.

4. Liu S, Manson JE, Lee IM, Cole SR, Hennekens CH, Willett WC, et al. Fruits and vegetable intake and risk of cardiovascular disease: the Women's Health Study. Am J Clin Nutr 2000; 72:922-8.

5. Ford ES, Mokdad AH. Fruits and vegetable consumption and diabetes mellitus incidence among U.S. adults. Prev Med 2001; 32:33-9.

6. Newby PK, Muller D, Hallfrisch J, Qiao N, Andres R, Tucker KL. Dietary patterns and changes in body mass index and waist circumference in adults. Am J Clin Nutr 2003; 77:1417-25.
7. Togo P, Osler M, Sorensen TIA, Heitmann BL. A longitudinal study of food intake patterns and obesity in adult Danish men and women. Int J Obes Relat Metab Disord 2004; 28:583-93.

8. Togo P, Osler M, Sorensen TIA, Heitmann BL. Food intake patterns and body mass index in observational studies. Int J Obes Relat Metab Disord 2001; 25:1741-51.

9. Galeazzi MAM, Domene SM, Sichieri R. Estudo multicêntrico sobre consumo alimentar. Cadernos de Debates 1997; v. esp.:1-62.

10. Fisberg RM, Morimoto JM, Slater B, Barros MBA, Carandina L, Goldbaum M, et al. Dietary quality and associated factors among adults living in State of São Paulo, Brazil. J Am Diet Assoc 2006; 106:2067-72.

11. Serra-Majem L. Food availability and consumption at national, household and individual levels: implications for food-based dietary guidelines development. Public Health Nutr 2001; 4:673-6.

12. Willett WC. Nutritional epidemiology. 2nd Ed. New York: Oxford University Press; 1998. 
13. Instituto Brasileiro de Geografia e Estatística. Pesquisa de Orçamentos Familiares - POF 2002/2003: análise da disponibilidade domiciliar de alimentos e do estado nutricional no Brasil. Rio de Janeiro: Instituto Brasileiro de Geografia e Estatística; 2004.

14. World Cancer Research Fund/American Institute for Cancer Research. Food, nutrition and the prevention of cancer: a global perspective. Washington DC: American Institute for Cancer Research; 1997.

15. Becker W, Helsing E. Food and health data. Their use in nutrition policy-making. Copenhagen: WHO Regional Office for Europe; 1991. (European Series, 39).

16. Instituto Brasileiro de Geografia e Estatística. Estudo Nacional das Despesas Familiares - ENDEF: 1974-1975. Rio de Janeiro: Instituto Brasileiro de Geografia e Estatística; 1978.

17. Alves MCGP. ISA-Capital: plano de amostragem. http://hygeia.fsp.usp.br/isa-sp/pdf/planoamos tralisacapital.pdf (accessed on 13/Aug/2009).

18. World Health Organization. Global strategy on diet, physical activity and health. Geneva: World Health Organization; 2004.

19. Asfaw A. Fruits and vegetables availability for human consumption in Latin American and Caribbean countries: patterns and determinants. Food Policy 2008; 33:444-54.

20. Food and Agriculture Organization. Food balance sheets: history, sources, concepts and definitions. http://www.foodsec.org/tr/stat/tr_taj_02_fbs.pdf (accessed on 13/Aug/2009).

21. Kantor LS, Kipton K, Manchester A, Oliveira V. Estimating and addressing America's food losses. Washington DC: Economic Research Service, U.S. Department of Agriculture; 1997.

22. Pomerleau J, Lock K, McKee M. Discrepancies between ecological and individual data on fruit and vegetable consumption in fifteen countries. $\mathrm{Br} \mathrm{J}$ Nutr 2003; 89:827-34.

23. Naska A, Berg M, Cuadrado C, Freisling H, Gedrich K, Gregoric M, et al. Food balance sheet and household budget survey dietary data and mortality patterns in Europe. Br J Nutr 2009; 102:166-71.

24. Kelly A, Becker W, Helsing E. Food balance sheets. In: Becker W, Helsing E, editors. Food and health data: their use in nutrition policy-making. Copenhagen: WHO Regional Office for Europe; 1991. (European Series, 39). p. 39-47.
25. Sarno F, Claro RM, Levy RB, Bandoni DH, Ferreira SRG, Monteiro CA. Estimativa de consumo de sódio pela população brasileira, 2002-2003. Rev Saúde Pública 2009; 43:219-25.

26. Moura EC, Morais Neto OL, Malta DC, Moura L, Silva NN, Bernal R, et al. Vigilância de fatores de risco para doenças crônicas por inquérito telefônico nas capitais dos 26 estados brasileiros e no Distrito Federal (2006). Rev Bras Epidemiol 2008; 11:20-37.

27. Bingham SA, Nelson M, Paul AA, Haraldsdottir J, Bjørge Løken E, van Staveren WA. Methods for data collection at an individual level. In: Cameron ME, van Staveren WA, editors. Manual on methodology for food consumption studies. New York: Oxford University Press; 1988. p. 53-106.

28. Emmett P. Workshop 2: the use of surrogate reporters in the assessment of dietary intake. Eur J Clin Nutr 2009; 63 Suppl 1:S78-9.

29. Vries JHM, Zock PL, Mensink RP, Katan MB. Underestimation of energy intake by $3-\mathrm{d}$ records compared with energy intake to maintain body weight in 269 nonobese adults. Am J Clin Nutr 1994; 60:855-60.

30. Kortzinger I, Bierwag A, Mast M, Muller MJ. Dietary underreporting: validity of dietary measurements of energy intake using a 7-day dietary record and a diet history in nonobese subjects. Ann Nutr Metab 1997; 41:37-44.

31. Black AE, Cole TJ. Within and between-subject variation in energy expenditure measured by the doubly-labelled water technique: implications for validating reported dietary energy intake. Eur J Clin Nutr 2000; 54:386-94.

32. Goldberg GR, Black AE, Jebb SA, Cole TJ, Murgatroyd PR, Coward WA, et al. Critical evaluation of energy intake data using fundamental principles of energy physiology: 1 . Derivation of cut-off values to identify under-recording. Eur J Clin Nutr 1991; 45:569-81.

33. Bueno MB, Marchioni DML, Cesar CL, Fisberg RM. Added sugars: consumption and associated factors among Brazilians adults and elderly. Rev Panam Salud Pública; in press.

Submitted on 31/Aug/2009

Final version resubmitted on 16/Dec/2009

Approved on 11/Mar/2010 